\title{
DIVERSITY AND NUMBERS OF ROOT-NODULE BACTERIA (RHIZOBIA) IN POLISH SOILS
}

\author{
Stefan Martyniuk, Jadwiga Oroń, Maria Martyniuk \\ Department of Agricultural Microbiology \\ Institute of Soil Science and Plant Cultivation \\ Czartoryskich 8, 24-100 Puławy, Poland \\ e-mail: iung@iung.pulawy.pl
}

(Received: April 6, 2004. Accepted: July 8, 2004)

\begin{abstract}
Using a sand pouch-plant infection method, populations of several species of root-nodule bacteria (rhizobia) were enumerated in eighty soils collected throughout Poland. Rhizobium leguminosarum bv. viciae (symbionts of pea, faba bean, vetch) and R. leguminosarum bv. trifolii (symbionts of clover) were detected in 77 and 76 soils, respectively. Most of these soils contained moderate and high numbers of these species of the rhizobia. Symbionts of beans, $R$. leguminosarum bv. phaseoli, were assessed in 76 soils; of this number 15 soils had no detectable populations of bean rhizobia and in 40 soils high or moderate numbers of these bacteria were found. Bradyrhizobium sp. (Lupinus), root-nodule bacteria of lupine and serradella, were absent in 19 soils, out of 80 tested, and 34 soils were colonised by high or moderate populations of bradyrhizobia. Sinorhizobium meliloti, rhizobia nodulating alfalfa, were sparse in the examined soils; with 56 soil containing no detectable numbers of $S$. meliloti and only 6 soils harbouring high or moderate populations of this species. The estimated numbers of the rhizobia in the studied soils were also related to some physical and chemical properties of these soils.
\end{abstract}

KEY WORDS: rhizobia, number, soil, legumes, soil properties.

\section{INTRODUCTION}

Root-nodule bacteria, fixing atmospheric nitrogen in the symbiosis with leguminous plants, are members of the following genera: Bradyrhizobium, Rhizobium, Sinorhizobium, Mesorhizobium, Azorhizobium and Allorhizobium within the family Rhizobiaceae (Małek and Sajnaga 1999). These bacteria, commonly known as rhizobia, survive in soil between symbiotic phases as saprophytes and their populations depend on many physical and chemical properties of the soil environment and on the frequency of planting of legumes in a given area or field (Sadowsky and Graham 1998). In a long-term plot experiment Martyniuk et al. (1999) assessed numbers of various species of rhizobia in two soils cropped to cereals and treated with different rats of mineral fertilisers (NPK), with or without liming. In the limed soils relatively high populations of rhizobia nodulating red clover or pea were found, though these legumes were not grown in this experiment for over 20 years, but in the unlimed soils populations of the rhizobia were markedly lower. Contrary to pea and clover rhizobia, almost no microsymbionts of alfalfa were detected in the studied soils, both limed and unlimed, indicating that the survival of alfalfa rhizobia in soil strongly depends on the presence of their host plant. Similar results were obtained by Nutman and Hearne (1979) for rhizobia in UK soils. In
France, Amarger (1980) analysed populations of various species of root-nodule bacteria in 60 different soils and related numbers of these bacteria to soil $\mathrm{pH}$. It was found in this study that populations of alfalfa rhizobia were much lower in soils with the $\mathrm{pH}$ below 6.0 than in neutral or alkaline soils, but the reverse was true for lupine rhizobia.

There is generally a lack of documented data on population levels of different species of rhizobia in Polish soils. Our preliminary studies with 20 field soils indicate that rhizobia nodulating red clover (Rhizobium leguminosarum bv. trifolii) and peas (R.l. bv. viciae) occur commonly, and in relatively high numbers, in the soils of Poland (Martyniuk et al. 2000). The aim of this work was to assess populations of several species of rhizobia in eighty soils samples collected throughout Poland.

\section{MATERIALS AND METHODS}

\section{Soils}

In the years 1999, 2000 and 2001 a total of eighty soils from different regions of Poland were sampled to assess numbers of root-nodule bacteria (rhizobia) occurring in these soils. Soil samples were collected in all provinces (voivodeships), but the number of the sampled field soils varied from 3 in the following provinces: Kujawsko-Po- 
morskie, Opolskie, Warmińsko-Mazurskie and Zachodniopomorskie to 11 in the Lubelskie Province. In September or October of each year soil samples were collected from the plough layer $(0-30 \mathrm{~cm})$. The soils were sieved through a $2 \mathrm{~mm}$-mesh screen and stored moist in a refrigerator for a period not longer than 2 weeks before they were assessed for the numbers of root-nodule bacteria. Sub-samples of the soils were air dried and analysed in the Certified Central Chemical Laboratory of the Institute of Soil Sc. and Plant Cultivation for the following physical and chemical properties: silt-clay content (sedimentation technique), organic $\mathrm{C}$ (dichromate digestion), total $\mathrm{N}$ (Kjeldahl) and $\mathrm{pH}$ (in $\mathrm{H}_{2} \mathrm{O}$ and $\mathrm{KCl}$ ). A history of crops grown in the fields from which the tested soils were collected was also traced beck as far as possible.

\section{Counting of rhizobia}

The tested soils were assessed for the numbers of fife species of root-nodule bacteria (rhizobia) listed in Table 1, in which the host plants of these bacteria are also given. A sand pouch-plant infection method was used to assess the most probable numbers (MPN) of the rhizobia in the studied soils (Martyniuk et al. 2000). Shortly, in this method seedlings of the test leguminous plants, shown in Table 1 , were grown under semi-aseptic conditions in plastic pouches filled with sterile sand moistened with $\mathrm{N}$-free nutrient solution to support plant growth. The seedlings were inoculated with $1 \mathrm{ml}$ of 10 -fold soil dilutions in water and grown in a plant growth chamber (Hereus HPS). In these tests we used six soil dilution steps (from $10^{1}$ to $10^{6}$ ) and two or four replicated pouches (seedlings) for each dilu- tion. The growth chamber was set at a $16 \mathrm{~h} / 8 \mathrm{~h}$ light-dark regime and at $22^{\circ} \mathrm{C}$ day $/ 15^{\circ} \mathrm{C}$ night temperature. After $4-6$ weeks of growth the roots of the seedlings were gently washed in tap water and inspected for the presence of nodules in each dilution and the total number of positive cases counted. Based on these scores the most probable numbers (MPN) of the rhizobia in the tested soils were calculated from mathematical tables (Vincent 1970). The numbers of the rhizobia in the tested soils were expressed per $1 \mathrm{~g}$ of soil d.m. (Table 2)

The numbers of the rhizobia were log transformed for calculation (using Excel program) of linear correlation coefficients with physical and chemical characteristics of the studied soil (Table 3).

\section{RESULTS AND DISCUSSION}

Due to the lack of selective agar media to enumerate rhizobia in soils, indirect soil dilution-plant infection methods are used to assess the most probable numbers (MPN) of these bacteria in the soil environment (Brockwell 1963; Vincent 1970; Weaver and Frederick 1972; Amarger 1980; Toomsan et al. 1984; Martyniuk et al. 2000). In these tests seedlings of the small-seeded legumes (e.g. alfalfa, clover) are usually grown easily in glass tubes with cotton plugs to control contamination, but growing of the large-seeded legumes (e.g. lupine, bean) in tubes, even in big ones, is difficult. For this reason we grow seedlings of the test legumes in sand pouches of different size (Martyniuk et al. 2000). Using the sand pouch-plant infection bioassays we

TABLE 1. The examined species of rhizobia, their host plants and number of soils in which the rhizobia were assessed.

\begin{tabular}{|c|c|c|c|}
\hline Species of rhizobia & Host legumes & Host species and cultivar used in the MPN plant infection tests & Number of soils \\
\hline Bradyrhizobium sp. & Lupinus, Ornithopus & O. sativus L., cv. Libella & 80 \\
\hline \multicolumn{4}{|c|}{ Rhizobium leguminosarum: } \\
\hline biovar trifolii & Trifolium & T. repens L., cv. Hruszowska & 80 \\
\hline biovar viciae & Vicia, Lathyrus, Pisum & P. arvense $\mathrm{L}$, cv. Fidelia & 80 \\
\hline biovar phaseoli & Phaseolus & Ph. vulgaris L., cv. Aura & 76 \\
\hline Sinorhizobium. meliloti & Medicago, Melilotus & M. sativa L., cv. Socza & 80 \\
\hline
\end{tabular}

TABLE 2. Examined soils grouped according to the number of rhizobia per soil unit.

\begin{tabular}{|c|c|c|c|c|c|c|}
\hline \multirow{2}{*}{ Group } & \multirow{2}{*}{$\begin{array}{l}\text { Population } \\
\text { of rhizobia }\end{array}$} & \multicolumn{5}{|c|}{ Number of rhizobia $1 \mathrm{~g}^{-1}$ of soil dry matter (number of soils - in brackets) } \\
\hline & & $\begin{array}{c}\text { Bradyrhizobium sp. } \\
\text { (Lupinus) }\end{array}$ & $\begin{array}{l}\text { R. leguminosarum } \\
\text { biovar vicae }\end{array}$ & $\begin{array}{l}\text { R. leguminosarum } \\
\text { biovar trifolii }\end{array}$ & $\begin{array}{l}\text { R. leguminisarum } \\
\text { biovar phaseoli }\end{array}$ & $\begin{array}{c}\text { Sinorhizobium } \\
\text { meliloti }\end{array}$ \\
\hline I & High & $\begin{array}{c}1.1 \times 10^{3}-2.8 \times 10^{4} \\
(24)\end{array}$ & $\begin{array}{c}1.7 \times 10^{3}-8.5 \times 10^{5} \\
(59)\end{array}$ & $\begin{array}{c}1.1 \times 10^{3}-7.9 \times 10^{5} \\
(43)\end{array}$ & $\begin{array}{c}1.7 \times 10^{3}-2.2 \times 10^{5} \\
(25)\end{array}$ & $\begin{array}{c}1.1-3.0 \times 10^{4} \\
\text { (3) }\end{array}$ \\
\hline II & Moderate & $\begin{array}{c}1.2 \times 0^{2}-9.0 \times 10^{2} \\
(10)\end{array}$ & $\begin{array}{c}1.7-7.1 \times 10^{2} \\
(11)\end{array}$ & $\begin{array}{c}1.1 \times 10^{2}-1.0 \times 10^{3} \\
(12)\end{array}$ & $\begin{array}{c}1.7-6.8 \times 10^{2} \\
(15)\end{array}$ & $\begin{array}{c}2.2-4.9 \times 10^{2} \\
\text { (3) }\end{array}$ \\
\hline III & Low & $\begin{array}{c}11-94 \\
(17)\end{array}$ & $\begin{array}{l}19-70 \\
(5)\end{array}$ & $\begin{array}{c}17-100 \\
(17)\end{array}$ & $\begin{array}{l}17-70 \\
(18)\end{array}$ & $\begin{array}{l}11-75 \\
(7)\end{array}$ \\
\hline IV & Very low & $\begin{array}{l}2-9 \\
(10)\end{array}$ & $\begin{array}{c}7 \\
(2)\end{array}$ & $\begin{array}{c}7 \\
(4)\end{array}$ & $\begin{array}{c}7 \\
(3)\end{array}$ & $\begin{array}{l}2-8 \\
(11)\end{array}$ \\
\hline
\end{tabular}


TABLE 3. Correlation between the number of rhizobia of different species in the examined soils and some chemical and physical characteristics of the soils.

\begin{tabular}{|c|c|c|c|c|c|c|}
\hline \multirow{3}{*}{ Species of rhizobia } & $\begin{array}{l}\text { C org. } \\
(\%)\end{array}$ & $\begin{array}{l}\mathrm{N} \text { total } \\
(\%)\end{array}$ & $\mathrm{pH}\left(\mathrm{H}_{2} \mathrm{O}\right)$ & $\mathrm{pH}(\mathrm{KCl})$ & $\begin{array}{l}\text { Soil fraction } \\
<0.02 \mathrm{~mm}(\%)\end{array}$ & $\begin{array}{c}\text { Soil fraction } \\
<0.002 \mathrm{~mm}(\%)\end{array}$ \\
\hline & \multicolumn{6}{|c|}{ Range in the tested soils } \\
\hline & $0.55-3.27$ & $0.04-0.30$ & 4.8-7.7 & $3.7-7.1$ & $7-61$ & $1-33$ \\
\hline Bradyrhizobium sp. (Lupinus) & -0.167 & $-0.279^{*}$ & $-0.241 *$ & -0.188 & $-0.529 * *$ & $-0.521 * *$ \\
\hline \multicolumn{7}{|l|}{ Rhizobium leguminosarum: } \\
\hline biovar viciae & -0.186 & -0.077 & $0.439 * *$ & $0.542 * *$ & -0.115 & -0.014 \\
\hline biovar trifolii & 0.119 & $0.282 *$ & $0.488 * *$ & $0.403 * *$ & $0.579 * *$ & $0.471 * *$ \\
\hline biovar phaseoli & 0.197 & $0.361 * *$ & 0.223 & 0.220 & $0.335^{* * *}$ & 0.172 \\
\hline Sinorhizobium meliloti & 0.187 & $0.264 *$ & 0.221 & 0.222 & $0.362 * *$ & $0.397 * *$ \\
\hline
\end{tabular}

* significant at $p=0.05 ; * *$ significant at $p=0.01$

estimated numbers of the following species of the rhizobia: Bradyrhizobium sp., Sinorhizobium meliloti and three groups (biovars) of Rhizobium leguminosarum: bv. trifolii, bv. viciae and bv. phaseoli in 80 soils (76 soils in the case of bv. phaseoli) collected from different regions of our country (Table 1).

\section{Bradyrhizobium sp. (Lupinus)}

Rhizobia nodulating lupine and serradella were not detected in 19 out of 80 soils tested (Group V, Table 2) and in the other 27 soils populations of these bacteria were low or very low (Groups III and IV). The soils of the groups III, IV and V made up almost $60 \%$ of the total number of the soils examined in this study. Moderate numbers of Bradyrhizobium sp. $\left(1.2-9.0 \times 10^{2}\right)$ were found in 10 soils and 24 soils contained high numbers (over 1000 cells in $1 \mathrm{~g}$ soil d.m.) of these rhizobia. Among the soils tested, only 4 soils originated from fields in which lupine or serradella were grown in the year of sampling or in the previous growing season. These soils contained the highest numbers (1.7 $-2.8 \times 10^{4}$ ) of Bradyrhizobium sp., proving that cultivation of the host-plants had beneficial effect on soil populations of these root-nodule bacteria (Nutman and Hearne 1979; Slattery and Coventry 1989). It should be added, however, that many soils harbouring moderate or high populations of Bradyrhizobium sp. (Groups I and II) were not planted to lupine or serradella for long period of time, in some cases even for more than 30 years. This fact indicate that bradyrhizobia have the capacity to survive in soil for many years in the absence of their host-plants and that their survival depends on various soil factors. As Table 3 shows, the numbers of Bradyrhizobium sp. were significantly (negatively) correlated with the contents of silt-clay fractions, with the total $\mathrm{N}$ contents and with the $\mathrm{pH}$ (in water) of the soils, indicating that the light-textured, acid soils are beneficial for the proliferation and survival of these root-nodule bacteria. Interestingly, in Poland (Barbacki 1972) and in other countries (Slattery and Coventry 1989) lupine is cultivated preferably on soils with similar characteristics. Moreover, Gołębiowska and Sypniewska (1962) demonstrated that the symbiotic process between lupine and Bradyrhizobium sp. was markedly disturbed or even inhibited in alkaline soils.

\section{Rhizobium leguminosarum bv. viciae (R.l.v.)}

Rhizobia forming the symbiosis with roots of vetch, pea and faba-bean were found almost in all the examined soils. Most of the soils (70) contained high and moderate populations of R.l.v. (Groups I and II, Table 2). Common occurrence of these bacteria in Polish soils could be explained, at least partially, by relatively frequent cultivation of the host plants of R.l.v. by farmers, since in 23 cases the studied soil originated from fields on which these crops (pea or faba-bean) were included in crop rotations. These soils contained generally high populations of R.l.v, but also many soils not planted to peas or faba-bean were rich in these root-nodule bacteria. Similar results were presented for French and British soils (Nutman and Hearne 1979; Amarger 1980). Only in 7 soils, tested in our studies, low or very low numbers of R.l.v. were found and in the remaining 3 soils no R.l.v. was detected. The soils with no detectable or very low populations of R.l.v. were very acid ( $\mathrm{pH}=3.7$ 4.2), and significant correlation coefficients between the soil populations of these rhizobia and the $\mathrm{pH}$ of the soils (Table 3) indicate that soil reaction is an important factor influencing the survival of R.l.v. in soils.

\section{R. leguminosarum bv. trifolii (R.l.t.)}

Symbionts of clover, similarly to R.l.v., were found in almost all the soils. High and moderate populations of the clover rhizobia occurred in 55 soils and low numbers of these bacteria were detected in 17 soils. Only 4 soils contained no detectable populations of R.l.t. and in 7 soils these populations were assessed as very low (Groups IV and V, Table 2). The majority of the soils harbouring microsymbionts of red clover were not planted to this crop for many years (with the exception of 3 soils) indicating that this species of the rhizobia can survive in soils for a long period of time, even in the absence of their host plant. Significant correlation between soil $\mathrm{pH}$ and the contents of siltclay fractions suggests the best survival of the clover rhizobia in medium or heavy soils of slightly acid or neutral $\mathrm{pH}$ (Table 3).

\section{R. leguminosarum bv. phaseoli (R.l.ph.)}

Rhizobia nodulating beans were examined in 76 soils and of this number in 15 soils (20\%) these bacteria were 
not detected (Table 2). In the other soils tested populations of the bean rhizobia varied from very low (in 3 soils) to high in 25 soils. Field bean was grown only on 3 of the tested soils and the numbers of R.l.ph. in these soils were high. Soil populations of the bean rhizobia showed significant correlation with the contents of total $\mathrm{N}$ as well as with the contents of $0.02 \mathrm{~mm}$ soil mechanical fraction in the soils (Table 3). These results indicate that the bean rhizobia are moderately sensitive to the absence of their host plant, and that the survival of these bacteria is favoured in soils with higher contents of the total $\mathrm{N}$ and the silt-clay mechanical fraction.

\section{Sinorhizobium meliloti}

This was the only species of the rhizobia which was not detected in the majority of the studied soil (Table 2). The soils with very low and low populations of the alfalfa rhizobia (Groups III, IV and V) made up almost $93 \%$ of all the tested soils (80). Only 3 soils originated from fields with the stands of alfalfa and all these soils contained high numbers of $S$. meliloti. These results clearly indicate that the presence and population levels of the alfalfa rhizobia in Polish soils are, similarly to soils in other countries (Nutman and Hearne 1979; Amarger 1980; Sadowsky and Graham 1998), strongly dependent on the cultivation of the host crop. Soil texture as represented by the contents of silt-clay fractions is also an important factor influencing the survival of $S$. meliloti in soil (Table 3 ).

\section{CONCLUSIONS}

1. Rhizobium leguminosarum bv. viciae (R.l.v.) and R. leguminosarum bv. trifolii (R.l.t.) occur commonly in Polish soils. Most of the soils examined contained moderate or high populations of these bacteria. No R.l.v. and R.l.t. were detected in 3 and 4 soils, respectively.

2. R. leguminosarum bv. phaseoli and Bradyrhizobium sp. (Lupinus) are less frequent in Polish soil (about 20-23\% of the tested soils contained no detectable populations of these bacteria), while Sinorhizobium meliloti, was the only species not found in the majority of Polish soils.
3. The occurrence and population densities of the rhizobia in the examined soils were related to the cropping history of the legume hosts and to some soil characteristics, particularly soil $\mathrm{pH}$.

\section{LITERATURE CITED}

AMARGER N. 1980. Aspect microbiologique de la culture des legumineuses. Le Selectionneur francais 28: 61-66.

BARBACKI S. 1972. Łubin. PWRiL, Warszawa, pp. 145.

BROCKWELL J. 1963. Accuracy of a plant-infection technique for counting populations of Rhizobium trifolii. Appl. Microbiol. 11: 377-383.

GOŁĘBIOWSKA J., SYPNIEWSKA U. 1962. The effect of the plant and of ecological conditions on development of symbiosis between Lupine and Rhizobium lupini. Acta Microbiol. Polonica 11: 319-328.

MAŁEK W., SAJNAGA E. 1999. Current taxonomy of the rhizobia. Acta Microbiol. Pol. 48 (2): 109-122.

MARTYNIUK S., WOŹNIAKOWSKA A., MARTYNIUK M. 1999. Effect of agricultural practices on populations of Rhizobium in some field experiments. Bot. Lithuanica, Suppl. 3: 99-102 .

MARTYNIUK S., WOŹNIAKOWSKA A., MARTYNIUK M. OROŃ J. 2000. A new sand pouch-plant infection technique for enumeration of rhizobia in soil. Acta Soc. Bot. Pol. 69: 257-261.

NUTMAN P.S., HEARNE R. 1979. Persistence of nodule bacteria in soil under long-term cereal cultivation. Rothamsted Raport for 1979, Part 2: 77-90.

SADOWSKY M.J., GRAHAM P.H. 1998. Soil biology of the Rhizobiaceae. In: Spaink H.P, Kondorosi A., Hooykaas P.J.J. (eds), The Rhizobiaceae, Kluwer Academic Publishers, Dordrecht, pp. 155-172.

SLATTERY J.F., COVENTRY D.R. 1989. Population of Rhizobium lupini in soils used for cereal-lupin rotations in Northeast Victoria. Soil Biol. Biochem. 21: 1009-1010.

TOOMSAN B., RUPELA O.P., MITTAL S., DART P.J., CLARK K.W. 1984. Counting Cicer-Rhizobium using a plant infection technique. Soil Biol. Biochem. 16: 503-507.

VINCENT J.M. 1970. IBM Handbook No. 15. A Manual for the Practical Study of Root-Nodule Bacteria. Blackwell, Oxford, pp. 164.

WEAVER R.W., FREDERICK L.R. 1972. A new technique for most-probable-number counts of rhizobia. Plant Soil 36: 219 -222 . 